\title{
Oxidatively Induced DNA Damage and Cancer
}

\author{
Miral Dizdaroglu* and Pawel Jaruga
}

Biochemical Science Division, National Institute of Standards and Technology, Gaithersburg, MD 20899, USA

\begin{abstract}
Oxidatively induced DNA damage is caused by endogenous and exogenous sources in living organisms. Many resulting DNA lesions are mutagenic and lead to mutations commonly found in cancer. Repairs mechanisms exist to repair this type of DNA damage. Unrepaired and accumulated DNA lesions may lead to carcinogenesis and other disease processes. Defects in DNA repair are associated with cancer. Oxidatively induced DNA lesions accumulate in cancerous tissues, possibly contributing to genomic instability and metastatic potential. Recent evidence suggests that some tumors may even possess increased DNA repair capacity, leading to therapy resistance. DNA repair inhibitors are being developed to target the repair pathways and increase the efficacy of cancer therapy. Oxidatively induced DNA lesions and DNA repair proteins are potential biomarkers for early detection, cancer risk assessment, prognosis and monitoring the therapy. Overall, accumulated evidence suggests that oxidatively induced DNA damage and its repair are important factors in carcinogenesis, and deserve more research to understand and fight cancer.
\end{abstract}

\section{Introduction}

Oxidative stress that generates oxygen-derived species has been implicated in the pathogenesis of a wide variety of disease processes including carcinogenesis and aging [1,2]. Oxygen-derived species including free radicals, most notably the highly reactive hydroxyl radical $\left(\bullet^{\bullet} \mathrm{OH}\right)$ cause oxidatively induced damage to DNA in living aerobic organisms. These species are formed by normal cellular metabolism and by exogenous sources such as ionizing radiations, UV radiation, redox-cycling drugs and carcinogenic compounds [3]. Hydroxyl radical reacts with DNA constituents at or near diffusioncontrolled rates, causing damage to the heterocyclic bases and the sugar moiety by a variety of mechanisms. In addition, ionizing radiationgenerated $\mathrm{H}$ atom $\left(\mathrm{H}^{\bullet}\right)$, also a free radical, and hydrated electron $\left(\mathrm{e}^{-}\right)$ add to double bonds of DNA bases, leading to modifications [4]. DNA damage is encountered by cellular repair systems and can be repaired by a number of repair mechanisms [2]. If repair systems of living cells fail, oxidatively induced DNA damage may lead to mutagenesis [1,2,5], and may thus be a significant source of genomic instability, a hallmark of human cancers [6-8]. Experimental and epidemiological evidence suggests that this type of DNA damage may be a major contributor to human cancer [7].

\section{Mechanisms of oxidatively induced DNA damage}

Hydroxyl radical reacts with DNA constituents by addition and abstraction. It adds to double bonds of heterocyclic DNA bases at diffusion-controlled rates with rate constants varying from $4.5 \times 10^{9}$ $\mathrm{M}^{-1} \mathrm{~s}^{-1}$ to $9 \times 10^{9} \mathrm{M}^{-1} \mathrm{~s}^{-1}$, and abstracts an $\mathrm{H}$ atom from the methyl group of thymine and from each of the $\mathrm{C}-\mathrm{H}$ bonds of 2'-deoxyribose with rate constants of approximately $2 \times 10^{9} \mathrm{M}^{-1} \mathrm{~s}^{-1}$ [1,4]. Ionizing radiation-generated $\mathrm{e}^{-}$aq reacts with DNA bases at diffusion-controlled rates with rate constants varying from $0.9 \times 10^{10} \mathrm{M}^{-1} \mathrm{~s}^{-1}$ to $1.7 \times 10^{10} \mathrm{M}^{-1}$ $\mathrm{s}^{-1}$, whereas the rates of $\mathrm{H}^{\bullet}$ reactions are lower and amount to $1-5 \times$ $10^{8} \mathrm{M}^{-1} \mathrm{~s}^{-1}$. Because of its electrophilic nature, ${ }^{\bullet} \mathrm{OH}$ preferentially adds to the site with the highest electron density. In the case of guanine, addition of ${ }^{\bullet} \mathrm{OH}$ to the $\mathrm{C} 4-, \mathrm{C}-5$ and $\mathrm{C}-8$ positions yields $\mathrm{C} 4-\mathrm{OH}-$, $\mathrm{C} 5-\mathrm{OH}-$ and $\mathrm{C} 8-\mathrm{OH}$-adduct radicals $[9,10]$. Adenine undergoes analogous reactions, yielding at least $\mathrm{C} 4-\mathrm{OH}-$ and $\mathrm{C} 8-\mathrm{OH}$-adduct radicals [11]. Dehydration of $\mathrm{C} 4-\mathrm{OH}-$ and $\mathrm{C} 5-\mathrm{OH}$-adduct radicals of adenine and guanine yields purine $(-\mathrm{H})^{\bullet}$ radicals, which are then reduced and protonated to reconstitute adenine and guanine $[1,10,12]$. C8-OH-adduct radicals of purines undergo one-electron oxidation and one-electron reduction to give rise to 8-hydroxypurines [8-hydroxyadenine (8-OH-Ade) and 8-hydroxyguanine (8-OH-Gua)] and formamidopyrimidines [4,6-diamino-5-formamidopyrimidine (FapyAde) and 2,6-diamino-4-hydroxy-5-formamidopyrimidine (FapyGua)], respectively. Both types of products are formed in the absence and presence of oxygen, albeit with different yields. Reducing agents favor the formation of formamidopyrimidines, whereas 8-hydroxypurines are preferentially produced by oxidizing agents [1].

Hydroxyl radical reacts with cytosine and thymine by addition to C5- and $\mathrm{C} 6$-positions yielding $\mathrm{C} 5-\mathrm{OH}-$ and $\mathrm{C} 6-\mathrm{OH}$-adduct radicals, respectively, and by abstraction of an $\mathrm{H}^{\bullet}$ from the methyl group of thymine generating an allyl radical. $\mathrm{C} 5-\mathrm{OH}-$ and $\mathrm{C} 6-\mathrm{OH}$-adduct radicals are oxidized followed by addition of water and subsequent deprotonation to yield cytosine glycol (Cyt glycol) and thymine glycol (Thy glycol) [1]. The oxidation of the allyl radical of thymine yields 5-(hydroxymethyl)uracil and 5-formyluracil. The type of the products and their yields vary depending on the absence and presence of oxygen that reacts with free radicals at diffusion-controlled rates to give peroxyl radicals. Depending on reaction conditions, cytosine products can dehydrate and deaminate, giving rise to products such as 5-hydroxycytosine (5-OH-Cyt), uracil glycol (Ura glycol) and 5-hydroxyuracil (5-OH-Ura) [13]. The formation of the products of DNA bases has been extensively studied in the past. It is beyond the scope of this paper to review all possible reactions. The reader is referred to extensive review articles published previously $[1,4,14]$. Clustered damage also occurs in DNA by oxidatively induced damage [15-18].

Figure 1 illustrates the structures of the major products of the DNA

*Corresponding author: Dr. Miral Dizdaroglu, Biochemical Science Division, National Institute of Standards and Technology, Gaithersburg, MD 20899, USA E-mail: miral@nist.gov

Received May 25, 2011; Accepted August 25, 2011; Published December 30 , 2011

Citation: Dizdaroglu M, Jaruga P (2011) Oxidatively Induced DNA Damage and Cancer. J Mol Biomark Diagn S2:002. doi:10.4172/2155-9929.S2-002

Copyright: (c) 2011 Dizdaroglu M, et al. This is an open-access article distributed under the terms of the Creative Commons Attribution License, which permits unrestricted use, distribution, and reproduction in any medium, provided the original author and source are credited 
<smiles>CC1(O)CNC(=O)NC1=O</smiles>

5-hydroxy-6-hydrothymine<smiles>CC1(O)NC(=O)NC(=O)C1(C)C</smiles>

thymine glycol<smiles>CC1(C)CNC(=O)NC1=O</smiles>

5,6-dihydrothymine<smiles>O=c1[nH]cc(CO)c(=O)[nH]1</smiles>

5-hydroxymethyluracil<smiles>O=Cc1c[nH]c(=O)[nH]c1=O</smiles>

5-formyluracil<smiles>CC1(O)NC(=O)NC1=O</smiles>

5-hydroxy-5-methylhydantoin<smiles>NC1=NC(=O)NC(O)C1(O)O</smiles><smiles>Nc1nc(=O)[nH]cc1O</smiles><smiles>Nc1nc(=O)[nH]c(O)c1O</smiles><smiles>CC1NC(=O)N=C(N)C1(O)O</smiles><smiles>CC1(O)NC(=O)NC(=O)C1(C)O</smiles><smiles></smiles>

cytosine glycol 5-hydroxycytosine

5,6-dihydroxycytosine

5-hydroxy-6-hydro-
cytosine

uracil glycol

5-hydroxyuracil<smiles>O=c1[nH]c(O)c(O)c(=O)[nH]1</smiles><smiles>O=C1NC(=O)[C@H](O)[C@H](O)N1</smiles><smiles>O=C1NC(=O)C(O)(O)N1</smiles><smiles>O=C1NC(=O)C(=O)C(=O)N1</smiles><smiles>CC1CNC(=O)NC1</smiles>

5,6-dihydroxyuracil

$$
\text { 5-hydroxy-6-hydro- }
$$

5-hydroxyhydantoin

alloxan

5,6-dihydrouraci<smiles>Nc1ncc2nc(O)[nH]c2n1</smiles><smiles>Nc1ncnc(N)c1NC=O</smiles><smiles>Nc1nc(O)nc2[nH]cnc12</smiles><smiles>Nc1nc2[nH]c(O)nc2c(=O)[nH]1</smiles><smiles>Nc1nc(N)c(N=O)c(=O)[nH]1</smiles>

8-hydroxyadenine

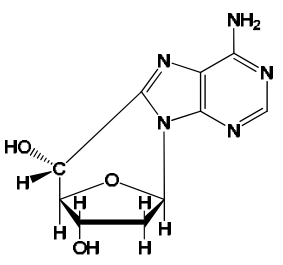

(5'R)-8,5'-cyclo-2'-deoxyadenosine

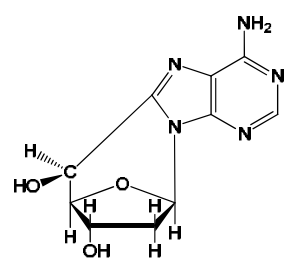

(5'S)-8,5'-cyclo-2'-deoxyadenosine

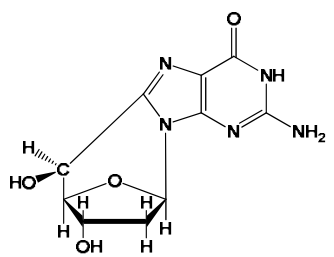

(5'S)-8,5'-cyclo-2'-deoxyguanosine
(5'R)-8,5'-cycla-2'-deoxyguanosine

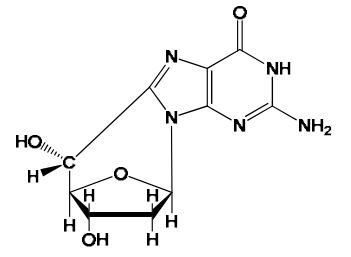<smiles></smiles>

thymine-tyrosine cross-link

Figure 1: Structures of major oxidatively induced DNA base lesions and a thymine-tyrosine cross-link. 
bases that have been identified in DNA in vitro and in vivo.

The sugar moiety of DNA undergoes reactions with ${ }^{\circ} \mathrm{OH}$ by abstraction of an $\mathrm{H}^{\bullet}$ from each of the $\mathrm{C}$-atoms, leading to five different $\mathrm{C}$-centered radicals. Further reactions of these 2'-deoxyribose radicals yield a number of sugar products, strand breaks and base-free sites in DNA by a variety of mechanisms $[1,4]$. Sugar products are either released from DNA or constitute the end groups of broken strands or remain within DNA with both phosphate linkages being intact. Figure 2 shows the structures of the products of the sugar moiety. One unique reaction of the 2'-deoxyribose radicals in purine nucleosides is the attack of the $\mathrm{C} 5$ '-centered sugar radical at the C8-position of the purine ring within the same nucleoside in the absence of oxygen leading to C5'-C8-intramolecular cyclization [19]. The rate constants for the intramolecular cyclization amounts to $1.6 \times 10^{5} \mathrm{~s}^{-1}$ and $\sim 1 \times 10^{6}$ $\mathrm{s}^{-1}$ for $\mathrm{dA}$ and $\mathrm{dG}$, respectively [20,21]. Subsequent oxidation of the $\mathrm{N}$-centered radical leads to 8,5'-Cyclopurine-2'- deoxyadenosine (cdA) from 2'-deoxyadenosine and 8,5'-Cyclopurine-2'-deoxyguanosine (cdG) from 2'-deoxyguanosine. Both $R$ - and $S$-diastereomers of each compound are formed. Oxygen inhibits the intramolecular cyclization [22], because it reacts with the C5'-centered radical of the sugar moiety at a near diffusion-controlled reaction with a rate constant of $\sim 1.9 \times$ $10^{9} \mathrm{M}^{-1} \mathrm{~s}^{-1}$ [20]. 8,5'-Cyclopurine-2'-deoxynucleosides represent a concomitant damage to both the base and sugar moieties of the same nucleoside, and thus, are regarded as tandem lesions in DNA. Another unique property of cdA and cdG is that they cause an unusual puckering of the sugar moiety leading to distortion of DNA helix $[23,24]$. The reaction mechanisms and formation of these compounds in vitro and in vivo has extensively been reviewed [25].

In addition, $\bullet \mathrm{OH}$ reactions with DNA and proteins in chromatin form covalent DNA-protein cross-links by different types of mechanisms. Thus, a thymine-tyrosine cross-link has been identified in mammalian chromatin in vitro and in vivo by exposure to free radical-generating agents such as ionizing radiation, $\mathrm{H}_{2} \mathrm{O}_{2}$, metal ions and carcinogenic compounds [26-28]. Other types of DNA protein cross-links have also been identified in mammalian chromatin in vitro. Figure 1 illustrates the structure of the thymine-tyrosine crosslink. DNA damage products can be measured in DNA by different analytical techniques. Mass spectrometric techniques are the most used ones that provide positive identification and accurate quantification of DNA products. This field has extensively been reviewed in the past by a number of authors [see, e.g., $[14,29]]$.

In the past two decades, numerous studies have shown elevated levels of aforementioned DNA base lesions in precancerous and cancerous tissues [30-41], strongly implicating oxidatively induced DNA damage in the etiology of cancer. As a result, oxidatively induced DNA base lesions have been suggested as potential sentinels for cancer risk assessment and therapy monitoring. The elevated levels of DNA lesions do not necessarily indicate that such DNA damage is responsible for carcinogenic events. However, most of these DNA lesions are strongly mutagenic and may thus be a major contributor to carcinogenesis, as will be discussed below.

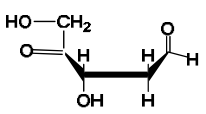

2-deoxypentose-4-ulose

?

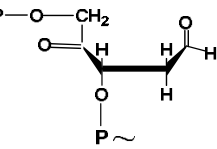

2-deoxypentose-4-ulose (within DNA)

?

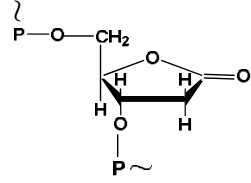

2-deoxypentonic acid lactone (within DNA)

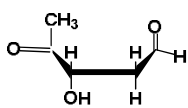

2,5-dideoxypentose-4-ulose

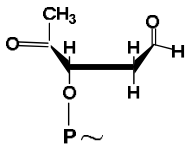

2,5-dideoxypentose-4-ulose (as a 5'-end group)

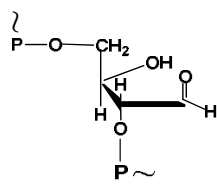

erythrose (within DNA)

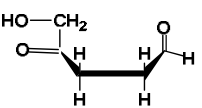

2,3-dideoxypentose-4-ulose

?

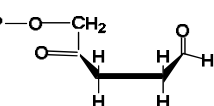

2,3-dideoxypentose-4-ulose (as a 3 '-end group)

l

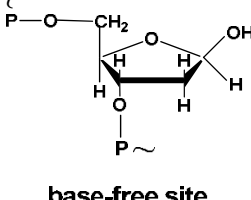

base-free site (within DNA)

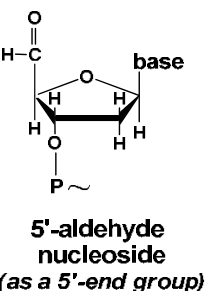

Figure 2: Structures of oxidatively induced lesions of the 2'-deoxyribose moiety of DNA. 


\section{Protection of the genomic stability}

DNA damage ultimately causes 80 to $90 \%$ of human cancers [42] The genomic instability caused by DNA damage is a hallmark of cancer $[8,43]$. Living organisms evolved to possess elaborate mechanisms to repair DNA damage to protect the genome from DNA damage for survival. DNA repair is essential for the maintenance of the genomic stability and prevention of disease processes including carcinogenesis $[2,44]$. As outlined above, a plethora of products are formed in DNA in vivo by reactions of ${ }^{\bullet} \mathrm{OH}$ and other free radicals. Failure to repair such DNA lesions may lead to mutagenesis, cytotoxicity, cell death and consequently to disease processes such as carcinogenesis and aging. Oxidatively induced DNA lesions are removed from DNA by two major mechanisms, base-excision repair (BER) and nucleotideexcision repair (NER) [2]. Both mechanisms involve multiple steps and enzymes to remove the lesions and subsequently restore the DNA structure. In BER, the enzymes known as DNA glycosylases remove DNA lesions by hydrolyzing the $N$-glycosidic bond between the modified base and the sugar moiety in the first step of this repair pathway, leaving behind an apurinic or apyrimidinic site (AP-site). Some DNA glycosylases are mono-functional and remove the lesion only. Others are also endowed with an associated AP-lyase activity that hydrolyzes the $3^{\prime}$-phosphodiester bond of the AP site by a $\beta$ - or $\beta$ - $\delta$-elimination mechanism generating a $3^{\prime} \alpha, \beta$-unsaturated aldehyde and $5^{\prime}$-phosphate products, and thus strand breaks [2]. BER is highly conserved from bacteria to humans and is a multiprotein pathway, which is different from NER because of the action of diverse DNA glycosylases rather than a multiprotein complex. BER is sub-divided into two pathways, short-patch and long-patch pathways. A bifunctional glycosylase predominantly initiates short-patch BER and a mono-functional glycosylase either pathway [45]. The removal of the lesion by a glycosylase is followed by the action of AP-endonucleases, DNA polymerases and DNA ligases that process the AP-sites to fully repair DNA. In the past three decades, numerous prokaryotic and eukaryotic DNA glycosylases have been isolated and purified, and their substrate specificities and excision kinetics have been determined (reviewed in [46]).

DNA glycosylases are generally divided into two families on the basis of structure and sequence homology, the Fpg/Nei family and the Nth superfamily [47,48]. The Fpg/Nei family includes Escherichia coli formamidopyrimidine DNA glycosylase (Fpg, also called MutM), which specifically excises FapyAde, FapyGua and 8-OH-Gua from DNA containing multiple lesions [46,49], and E. coli endonuclease VIII (Nei), which is specific for the removal of pyrimidine lesions and FapyAde [46]. Another major DNA glycosylase of E. coli, endonuclease III (Nth) belongs to the Nth superfamily and possesses an overlapping substrate specificity with Nei, removing pyrimidine lesions and FapyAde [46]. In eukaryotes, three Fpg/Nei homologs, NEIL1, NEIL2 and NEIL3 have been discovered [50-53]. NEIL1 and NEIL3 specifically remove FapyAde and FapyGua from DNA and also some pyrimidine lesions to a lesser extent; however, they exhibit no activity for 8-OH-Gua [50,54-56]. Figure 3 illustrates a comparison of the substrate specificities of mouse NEIL1 and NEIL3 (glycosylase domain) with those of some E.coli glycosylases. NEIL2 exhibits no significant sequence homology to NEIL1 and is independent of cell cycle expression [52,57]. This enzyme possesses a unique preference for excision from DNA bubbles generated during transcription and/ or replication, and preferentially excises 5-OH-Ura with some lower activity for 5-OH-Cyt and 5,6-dihydrouracil [52]. However, excision of any lesion by NEIL2 from DNA containing multiple lesions has not yet been reported. The Nth superfamily contains 8 -hydroxyguanine-

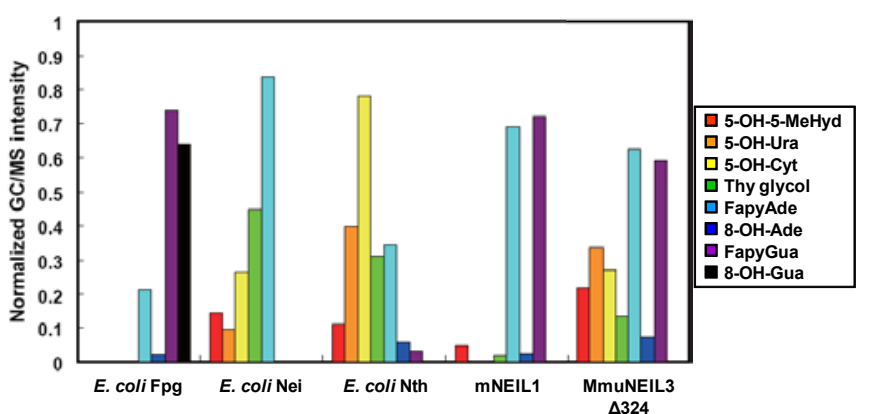

Figure 3: Comparison of the substrate specificities of $E$. coli DNA glycosylases with those of mouse NEIL1 and NEIL3. The normalized levels of excised lesions are shown (data from ref. [56]).

DNA glycosylase (OGG1) in eukaryotes, which is a functional homolog of Fpg, and exhibits a strong specificity for excision of FapyGua and 8-OH-Gua, but not FapyAde, unlike Fpg and NEIL1 [58,59]. Different substrate specificities of NEIL1 (mouse and human), E. coli Fpg and human OGG1 for purine lesions are clearly demonstrated in Figure 4.

NER is a major versatile repair mechanism for removal of bulky DNA-distorting lesions from DNA such as cyclobutane pyrimidine dimers, benzo[a]pyrene-guanine adducts and guanine-cisplatin adducts $[60,61]$. NER consists of global genome repair, which is responsible for the repair of the entire genome, and transcriptioncoupled repair, which preferentially repairs transcribing DNA strands [62-64]. Several syndromes are associated with defects in NER. For example, NER-defective xeroderma pigmentosum exhibits dramatic increase in sun-induced skin cancer. In prokaryotes and eukaryotes, an excinuclease, which is a multisubunit enzyme system, makes dual incisions in the DNA strand to remove an oligodeoxynucleotide containing the lesion. This is followed by the action of polymerases to fill the resulting gap and ligation by ligases to complete the repair. The removed oligodeoxynucleotide contains 12-13 deoxynucleotides in prokaryotes and 24-32 deoxynucleotides in eukaryotes [60,65] Human excinuclease is also involved in the repair of other lesions that do not distort DNA helix such as AP-sites, methylated bases and mismatches [66]. Repair by NER of oxidatively induced lesions Thy glycol and 8-OH-Gua has been reported [67,68]. 8,5'-Cyclopurine-2'deoxynucleosides are repaired by NER only, because the $8,5^{\circ}$-covalent bond in these molecules prevents their removal by DNA glycosylases [69-72].

Mismatch repair (MMR) is another major mechanism involved in the removal of nucleotides that are incorrectly paired with a correct nucleotide on the opposite DNA strand during replication [2]. In the case of oxidatively induced DNA damage, 8-OH-Gua mispairs with Ade during replication, forming the Ade $\bullet-\mathrm{OH}-\mathrm{Gua}$ mismatch. In E.coli, Ade is removed from this mismatch by the DNA glycosylase MutY, facilitating the pairing of 8-OH-Gua with Cyt, which is then repaired by BER [73]. The human homolog of this enzyme MUTYH has been identified [74]. Both enzymes belong to the Nth superfamily. MUTYH is targeted to both the nucleus and the mitochondrion [73,7578]. MUTYH also removes 2-OH-Ade from opposite all four intact DNA bases [78]. There is a compelling amount of data supporting the evidence that inherited mutations in the mutyh gene predispose individuals to colorectal cancer and somatic $\mathrm{G} \rightarrow \mathrm{T}$ mutations $[73,79$ 82]. This indicates the importance of MUTYH in preventing human carcinogenesis. No other DNA base lesions in mismatches have been found to be substrates of MUTYH. FapyGua, which is another highly 

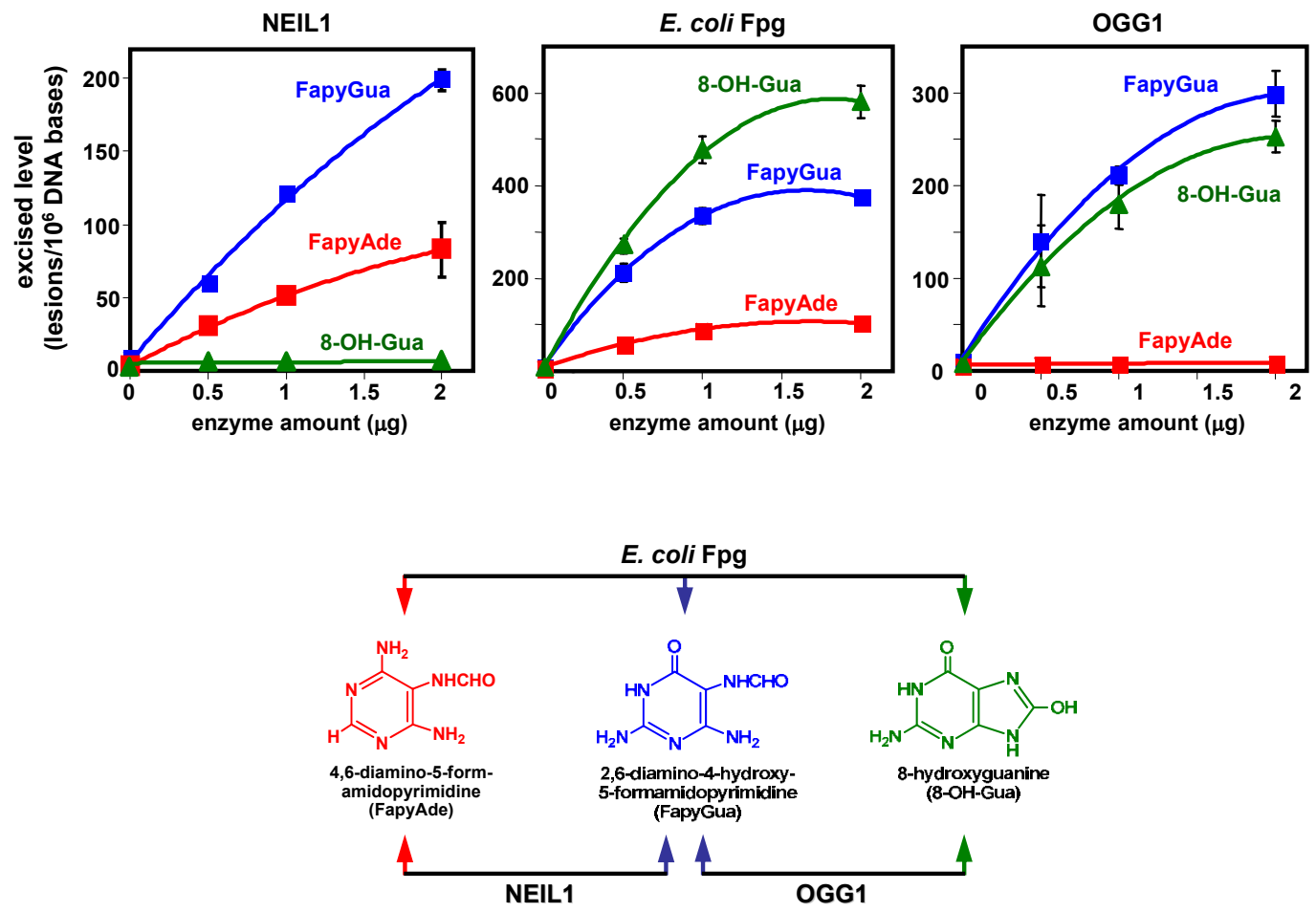

Figure 4: Comparison of the substrate specificities of E. coli Fpg, mouse NEIL1 and human OGG1. The uncertainties are standard deviations (data from refs. $[49,54,58])$

mutagenic Gua lesion and gives rise to $\mathrm{G} \rightarrow \mathrm{T}$ mutations (see above) associated with MUTYH and colorectal cancer, should be investigated for its potential to be a substrate of MUTYH and its role in colorectal cancer.

Repair in the nucleotide pool also occurs, hydrolyzing oxidized 2'-deoxynucleoside triphosphates to monosphates thus functionally eliminating them before they can be inserted into DNA by DNA polymerases [83-85]. The MutT protein of E. coli hydrolyzes 8-OHdGTP to 8-OH-dGMP and prevent its incorporation into DNA [83]. 8-OH-dGMP cannot be rephosphorylated by guanylate kinase. A mammalian homolog of this enzyme with the same function has also been discovered and named MTH1 protein $[84,86]$. Human MTH1 and E. coli MutT possess some sequence homology and similar molecular mass [87]. Mth $1^{-1-}$ mice have been found to be prone to spontaneous carcinogenesis with many tumors found in lungs and livers $[87,88]$. MTH1 also hydrolyzes 8-OH-dATP and 2-OH-dATP [89], pointing to an important role of human MTH1 protein in prevention of mutagenesis and consequently carcinogenesis. Another type of oxidatively induced damage to DNA is DNA single- and double-strand breaks, which present a threat to the genomic integrity. Single strand breaks are repaired in a fashion similar to that discussed in the case of BER. However, repair of double-strand breaks is more complex and occurs by either homologous recombination or non-homologous endjoining mechanisms $[90,91]$.

\section{DNA repair and cancer}

Unrepaired and accumulated DNA lesions may have detrimental consequences in living organisms. Resulting increase in mutation rate, i.e., mutator phenotype, can lead to increased genetic instability, which is a hallmark of cancer $[6,8,43]$. Genetic instability may affect gene expressions involved in many cellular processes such as DNA replication, DNA repair, apoptosis, etc. [92]. Single GC $\rightarrow$ AT transitions are the most frequent mutations that accumulate in human tumors [93]. 60\% of cancer cell lines have somatic mutations in DNA repair genes (for example, see http://www.sanger.ac.uk/genetics/CGP). Germline mutations and polymorphisms in DNA repair genes are also linked to predisposition to cancer $[2,8,43,44,94-96]$. Thus, DNA repair plays a major role in carcinogenesis and many other disease processes. A variety of cancers are associated with defects in DNA repair $[8,92,94$ 102]. Numerous studies demonstrated an association of OGG1-Cys ${ }^{326}$, a polymorphic form of OGG1 with the risk of esophageal, colon, orolaryngeal, lung, gastric, cervical, gallbladder, head, neck, kidney and bladder cancers [103-118]. Mutant forms OGG1-His ${ }^{154}$ and OGG1$G \mathrm{ln}^{46}$ have been discovered in a human gastric cancer cell line and human kidney tumors, respectively [104,119]. Moreover, low OGG1 activity has been shown to constitute a risk factor in lung, head and neck cancers [120-124]. It should be pointed out that OGG1-Cys ${ }^{326}$, OGG1-His ${ }^{154}$ and OGG1-Gln ${ }^{46}$ exhibit lower activity for the excision of FapyGua and 8-OH-Gua from DNA than wild type OGG1 [58,59]. This fact may indicate a role for these mutagenic lesions in carcinogenesis.

Mammalian NEIL1 has been isolated and characterized by a number of laboratories [50,51,53-55,57,125-131]. Activation of NEIL1 depends on cell cycle. NEIL1 is expressed predominantly during the S-phase and thus likely to be associated with replication-associated and/or transcription-coupled repair $[50,132,133]$. Similar to E. coli Nei and Fpg, this enzyme contains a "zinc-less finger" motif [127]. Human NEIL1 and mouse NEIL1 possess identical substrate specificities and efficiently excise FapyAde and FapyGua from DNA containing multiple lesions with somewhat reduced activity for pyrimidine lesions and with 


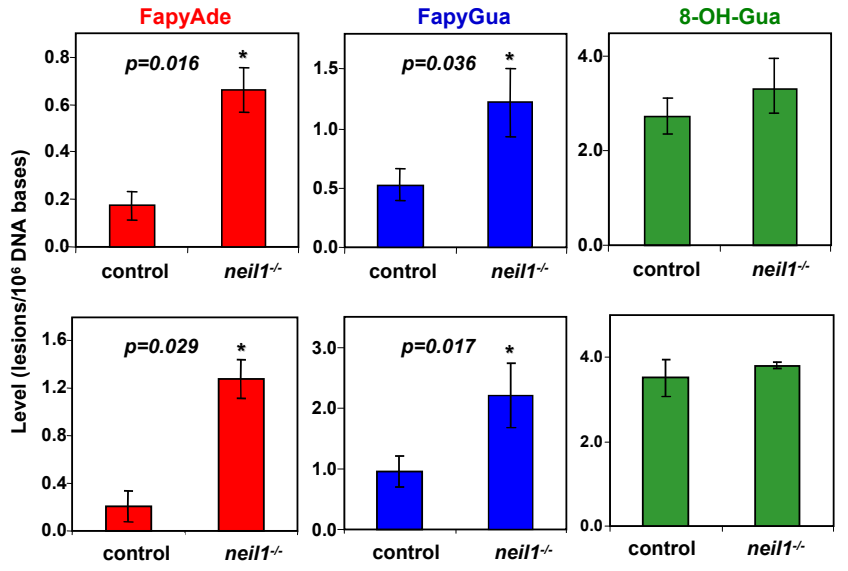

Figure 5: Levels of FapyAde, FapyGua and 8-OH-Gua in livers (upper) and kidneys (lower) of control and neil1-1- mice. Stars denote statistical significance $(p<0.05)$. The uncertainties are standard deviations (data from ref. [137]).
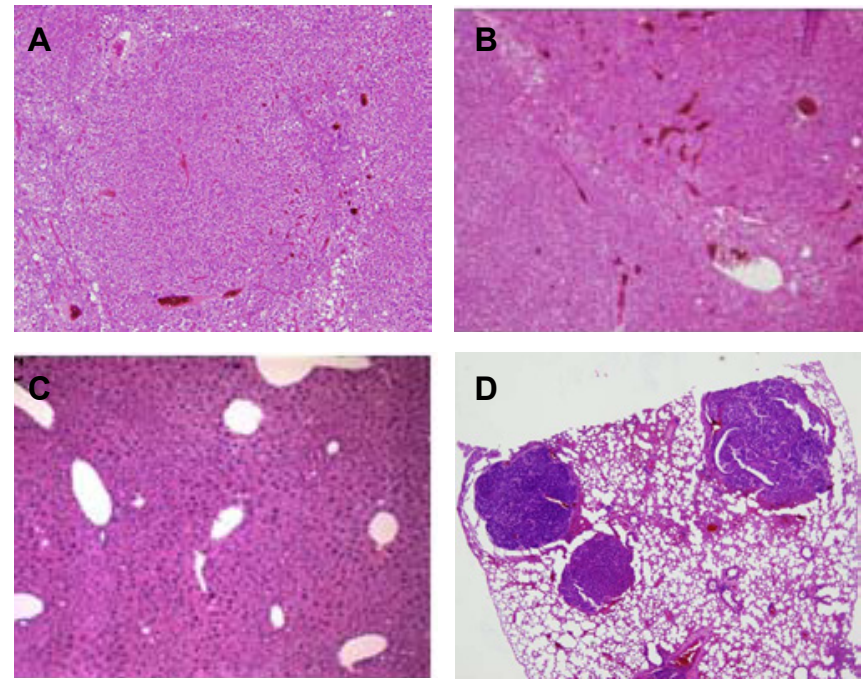

Figure 6: Histological sections of liver tumors, pre-malignant livers and lung tumors of knock-out mice. A: Nodular hyperplasia of hepatocytes in neil1-1mice; B: hepatocellular carcinoma in $n t h 1^{-1-}$ mice; C: Severe hepatocellular

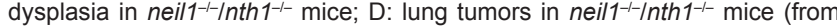
ref. [137]).

no activity for 8-OH-Gua unlike Fpg and OGG1 [50,54,55,131]. NEIL1 is located to both the nucleus and mitochondrion [129], suggesting the involvement of this enzyme in the overall maintenance of the genomic integrity. Four polymorphic variants of NEIL1, NEIL1-Cys ${ }^{82}$, NEIL1-Asp ${ }^{83}$, NEIL1-Asn ${ }^{252}$ and NEIL1-Arg ${ }^{136}$ have been discovered in humans [55]. NEIL1-Cys ${ }^{82}$ and NEIL1-Asn ${ }^{252}$ exhibited near wild type glycosylase activity for FapyAde and FapyGua. In contrast, NEIL1$A_{s p}{ }^{83}$ completely lacked this activity and also failed to catalyze the wild type $\beta, \delta$-elimination reaction, only exhibiting $\beta$-elimination. These findings suggest that individuals with neill mutations may be at risk for disease development. Recent work pointed to a significant role of NEIL1 in the prevention of disease processes. Decreased levels of NEIL1 led to accumulation of oxidatively induced DNA damage and enhanced spontaneous mutations in human and Chinese hamster cells [133]. Downregulation of NEIL1 expression by siRNA sensitized mouse embryonic stem cells to killing effects of ionizing radiation [126]. Oxidative stress increased neil1 mRNA levels in human carcinoma cells [134]. There is evidence for a correlation of mutations in the neil1 gene with human gastric cancer [135]. In the absence of exogenous oxidative stress, neil1 $1^{-1-}$ mice exhibited increased levels of mitochondrial DNA damage and deletions, and symptoms of diseases associated with the metabolic syndrome, suggesting a significant role for NEIL1 in disease prevention [136]. In a subsequent study, neil1 $1^{-1-}$ mice have been shown to accumulate greater levels of FapyAde and FapyGua, but not 8-OHGua, in their livers, kidneys and brains than control animals [137]. Figure 5 illustrates the levels of FapyAde, FapyGua and 8-OH-Gua in livers and kidneys of control and neil1 $1^{-/-}$mice. This finding is on a par with the substrate specificity of mouse NEIL1 and human NEIL1, which was previously observed in vitro using DNA containing multiple lesions, as discussed above. Neil1 $1^{-1-}$ mice developed pulmonary and hepatocellular tumors in the second half of their lives [137]. Additional knockout of the $n t h 1$ gene in these animals significantly increased the tumor incidence, indicating an important role for NEIL1 and NTH1 in cancer prevention. Figure 6 illustrates histological sections of liver tumors, pre-malignant livers and lung tumors of neil1 ${ }^{-/}, n t h 1^{-/-}$and neill $1^{-1-} /$ nth $1^{-1-}$ mice. The pulmonary tumors contained activating GGT $\rightarrow$ GAT transitions in codon 12 of $K$-ras of their DNA. This is in contrast to the GGT $\rightarrow$ GTT transversions of codon 12 in $\mathrm{K}$-ras found in the pulmonary tumors of mice lacking OGG1 and MUTY [138]. The accumulation of FapyAde and FapyGua in neil1 $1^{-1-}$ mice strongly suggests a role for these compounds in carcinogenesis, which are mutagenic as discussed below.

An additional function of NEIL1 has recently been discovered. Significant accumulation of $R$-cdA and $S$-cdA has been observed in livers of $n e i l 1^{-/-}$mice, but not in $\operatorname{ogg} 1^{-/-}$mice [139]. Figure 7A illustrates the levels of S-cdA in control, neil1 $1^{-/-}$and $\operatorname{ogg} 1^{-/-}$mice. Since $R$-cdA and $S$-cdA are repaired by NER, not by BER, as discussed above, this finding strongly suggests that NEIL1 plays a role in NER in addition to its role as a DNA glycosylase in BER. This work also showed the accumulation of FapyGua, but no accumulation of 8-OH-Gua, in livers of neil1 $1^{-1-}$ mice; however, ogg $1^{-/-}$mice accumulated 8-OH-Gua along with FapyGua [Figure 7B,C]. These findings are on a par with those reported previously [137], and with the substrate specificity of NEIL1 $[50,54,55,131]$. Accumulation of 8-OH-Gua and FapyGua in livers of ogg1 $1^{-/-}$mice is in agreement with the substrate specificity of OGG1 [58]. Mechanism of action of NEIL1 in NER is not known. In this context, Cockayne syndrome B protein has been shown to stimulate the repair
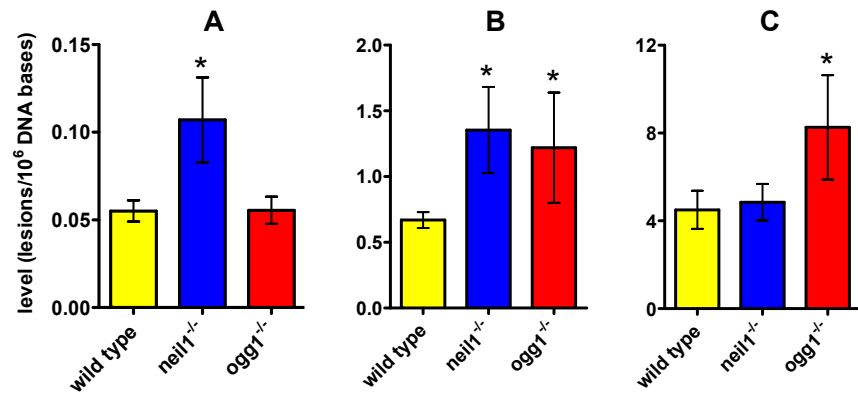

Figure 7: Levels of S-cdA (A), FapyGua (B) and 8-OH-Gua (C) in livers of control, neil1 $1^{--}$and ogg $1^{-/-}$mice. Stars denote statistical significance $(p<0.05)$. The uncertainties are standard deviations (from ref. [139]). 
of FapyAde and FapyGua by NEIL1 and play a role in NER of S-cdA $[131,140]$. This indicates that NEIL1 may interact with other proteins of the NER complex. Future studies may elucidate the mechanism of action of NEIL1 in NER.

Defective expression of DNA repair genes may affect DNA repair status of tumors and thus cause therapy resistance, and affect the outcome of cancer and survival of patients [141-143]. DNA repair may be increased in malignant tumors as recent evidence suggests. Nonsmallcell lung cancer has been shown to exhibit resistance to chemotherapy, which is associated with elevated DNA repair in tumors [141,143]. Greater overexpression of ogg1 mRNA for the excision of 8-OH-Gua has been observed in a number of lung cancer cell lines when compared to control lung cell lines [144]. Cancerous colon tissues exhibited lower levels of ethano-DNA adducts than non-cancerous tissues of colorectal cancer patients, indicating enhanced DNA repair in cancerous tissues $[145,146]$. During evolution of cancer, additional mutations resulting in an increase in genetic instability may provide cancerous cells with survival advantage. In contrast, increased mutations may also cause cell death late in tumor evolution. However, tumors that overexpress DNA repair genes may be favored by natural selection to become capable of surviving. With time, tumors may develop greater DNA repair capacity than non-cancerous tissues. Increased DNA repair in cancerous tissues may cause resistance to therapeutic agents and thus affect patient survival. These facts suggest that DNA repair capacity of tumors would be an essential factor to be determined prior to treatment. Thus far, accumulated evidence points to DNA repair proteins as important predictive, early detection, prognostic and therapeutic factors in cancer [95]. In this context, DNA repair pathways are promising drug targets for cancer treatment. DNA repair inhibitors are being developed to reduce DNA repair in cancerous tissues and thus increase the efficacy of therapy $[95,96]$. Selective development of DNA repair inhibitors for combination therapy or as single agents for monotherapy targeting both BER and NER pathways will be of outmost importance for future advances in cancer therapy.

\section{Biological effects of oxidatively induced DNA damage}

Among the oxidatively induced DNA lesions, 8-OH-Gua has been investigated extensively for more than 25 years, perhaps at the expense of other lesions that may be equally important. 8-OHGua has been found to be strongly mutagenic and mispair with Ade leading to $\mathrm{G} \rightarrow \mathrm{T}$ transversions [147-150], which are the second most common somatic mutations found in human cancers, with $14.6 \%$ of all mutations in the tumor suppressor gene TP53 following $\mathrm{C} \rightarrow \mathrm{T}$ transition mutations [44.2\%] [151]. However, this does not mean that all $\mathrm{G} \rightarrow \mathrm{T}$ mutations result from $8-\mathrm{OH}-\mathrm{Gua}$. Other Gua lesions may lead to this type of mutations such as FapyGua, another major oxidatively induced product of guanine. Albeit to a lesser extent, 8-OH-Ade is premutagenic and induces $A \rightarrow G$ transitions and $A \rightarrow C$ transversions in mammalian cells [152-154]. The other major purine lesions FapyAde and FapyGua also posses mutagenic properties. Early studies suggested that these lesions were lethal rather than mutagenic. This was based on the inference with lethal lesions N7-Me-FapyAde and N7-Me-FapyGua, which are alkylation products of Ade and Gua, respectively, [155-159], unlike FapyAde and FapyGua, the formation mechanism of which was discussed above. Recently, base-pairing properties and biological effects of FapyAde and FapyGua have definitively been established using synthetic oligodeoxynucleotides containing these compounds at a defined position. FapyAde pairs with Ade leading to $\mathrm{A} \rightarrow \mathrm{T}$ transversions and may be more mutagenic than 8-OH-Ade $[160,161]$. Similarly, Ade is misincorporated opposite
FapyGua, resulting in $\mathrm{G} \rightarrow \mathrm{T}$ transversions [162]. This is the same mutation caused by $8-\mathrm{OH}-\mathrm{Gua}$, as discussed above. FapyGua has been found to be $25-35 \%$ more mutagenic than $8-\mathrm{OH}-\mathrm{Gua}$ in simian kidney cells (COS-7) [161], although it is weakly mutagenic in E. coli, when bypassed in different sequence contexts [163]. These findings clearly proved, in contrast to the common assumption in the literature, that the well known $\mathrm{G} \rightarrow \mathrm{T}$ mutations may not be exclusively due to $8-\mathrm{OH}$ Gua as a result of oxidatively induced damage to DNA, and that the biological effects of FapyAde and FapyGua completely differ from those of N7-Me-FapyAde and N7-Me-FapyGua. 2-Hydroxyadenine, which is a minor product of Ade [164], is mutagenic in prokaryotic and eukaryotic cells, and pairs with Cyt leading to $A \rightarrow G$ transitions [165]. Its pairing with Ade has also been reported [166].

The major oxidatively induced product of Cyt is Cyt glycol, which yields 5-OH-Cyt by dehydration, Ura glycol by deamination and 5-OH-Ura by deamination and dehydration [13]. All these compounds may simultaneously exist in DNA [167]. Ura glycol and 5-OH-Ura pair with Ade and efficiently induce $\mathrm{C} \rightarrow \mathrm{T}$ transitions [5,168-170]. This is the most frequently observed mutation resulting from oxidatively induced DNA damage [171,172]. 5-OH-Cyt is less mutagenic than Ura glycol and 5-OH-Ura and leads to $\mathrm{C} \rightarrow \mathrm{T}$ transitions as well as $\mathrm{C} \rightarrow \mathrm{G}$ transversions$[169,172,173]$. Tandem double CC $\rightarrow$ TT mutations have also been observed due to oxidatively induced DNA damage; however, the identity of the Cyt product(s) leading to these mutations is not known [174]. Thy glycol, which is the most extensively studied pyrimidine lesion, pairs with Ade and is poorly mutagenic $[5,175,176]$. However, when inserted into a bypass sequence, a low level of pairing with Gua also occurs giving rise to $\mathrm{T} \rightarrow \mathrm{C}$ transitions [177]. Thy glycol is a strong block to most DNA polymerases in vitro, and thus a strongly lethal lesion in vivo $[5,175,176,178-180]$. Other pyrimidine lesions listed in Figure 1 are either weakly mutagenic or lethal lesions $[1,5]$.

Biological consequences of $8,5^{\prime}$-cyclopurine- 2 -deoxynucleosides have been investigated in the past decade. $S$-cdA is a strong block to DNA polymerases and reduces transcription by blocking transcription binding factor, reducing gene expression [71,72,181,182]. Furthermore, S-cdA causes transcriptional mutagenesis [183], which occurs when prokaryotic RNA polymerases bypass non-bulky DNA lesions such as modified DNA bases [184]. Mutant transcripts resulting from bypass of S-cdA by RNA polymerase II in vivo have been characterized [183]. Bypass of $S$-cdA by RNA polymerase II misincorporates an adenosine opposite to the next nucleotide 5'- to $S$-cdA and causes multiple nucleotide deletions [183]. S-cdA may give rise to neuronal death in a number of diseases such as NER-defective xeroderma pigmentosum by blocking neuronal gene expression [185]. A more recent work showed that $S$-cdG is a strong block to replication and a highly mutagenic lesion leading to $G \rightarrow A$ transitions with $G \rightarrow T$ transversions to a lesser extent, and is inefficiently repaired in E. coli [186]. Elevated levels of $8,5^{\prime}$-cyclopurine-2'-deoxynucleosides in genomic DNA in vivo in a number of diseases including cancer suggest that these lesions may play a role in carcinogenesis and other disease processes [25,38,187-190].

\section{Oxidatively induced DNA lesions and DNA repair proteins as biomarkers}

The findings reviewed above suggest that DNA lesions and DNA repair proteins may serve as potential biomarkers for cancer risk assessment and monitoring of the therapy. Noninvasive biomarkers such as those found in human urine have been extensively investigated. DNA lesions excreted into urine may be used as tumor markers for diagnosis, early detection and therapy monitoring, as well as in 
population-based studies such as epidemiological investigations. In terms of oxidatively induced DNA damage, early studies suggested two oxidatively modified DNA nucleosides, 8-hydroxy-2'-deoxyguanosine (8-OH-dG) and 2'-deoxythymidine glycol as suitable biological markers [191,192]. Since then, 8-OH-dG and its free base 8-OH-Gua in urine have been the mostly investigated lesions as biomarkers, albeit with some significant controversy in terms of the measurement by different analytical techniques between laboratories (reviewed in [193]). The source of these lesions in urine has also been debated for some time. In general, the possible sources of oxidatively induced DNA lesions have been considered to be diet, cell death/turnover and DNA repair [194]. Some recent work provided strong evidence that diet does not significantly contribute to the urinary levels of 8-OH-dG and 8-OH-Gua [195]. This may also be true for cell death [196,197]. BER is a likely source for the presence of 8-OH-Gua in urine [198], since this lesion is efficiently removed from DNA by OGG1 as was discussed above. However, this repair pathway cannot remove the nucleoside 8-OH-dG. It is not clear how DNA repair would remove this lesion. NER may excise 8-OH-dG and 2'-deoxythymidine glycol within an oligodeoxynucleotide as was discussed above. However, no oligodeoxynucleotides containing 8-OH-dG have been identified in human urine [196]. Further processing of such oligodeoxynucleotides by unknown mechanisms may yield $8-\mathrm{OH}-\mathrm{dG}$. The nucleotide pool may also be a major source of $8-\mathrm{OH}-\mathrm{dG}$ in urine $[199,200]$. Whatever the source of $8-\mathrm{OH}-\mathrm{dG}$ or $8-\mathrm{OH}-\mathrm{Gua}$ is in human urine, these lesions appear to be potential biomarkers, especially for DNA repair activity in tumors. Other modified DNA bases such as 5-OH-Ura, 8-OH-Ade and FapyGua have also been identified in urine as potential biomarkers [201,202]; however, these lesions have thus far not received as much attention as $8-\mathrm{OH}-\mathrm{dG}$ or $8-\mathrm{OH}-\mathrm{Gua}$. A more recent work discovered the presence of $R$-cdA and $S$-cdA as free nucleosides in human urine [203]. These lesions are subject to NER rather than BER (see above); therefore, their source in urine is likely to be NER. This suggests that $R$-cdA and $S$-cdA may serve as alternative well-suited biomarkers for cancer.

As was discussed above, DNA repair capacity is a risk factor for carcinogenesis. DNA repair pathways are promising drug targets and DNA repair inhibitors are being developed to inhibit the activity of DNA repair proteins in tumors to enhance the efficacy of cancer therapy $[95,96]$. All the accumulated evidence points to DNA repair proteins as early detection, prognostic and therapeutic biomarkers in cancer. For this purpose, the accurate measurement of these proteins in normal and cancerous human tissues will be of outmost importance. As a first step in this direction to positively identify and accurately quantify DNA repair proteins, we recently developed methodologies using mass spectrometric techniques with isotopically labeled analogues of these proteins as internal standards [204,205]. More efforts will have to be spent to assess DNA repair proteins as suitable biomarkers in cancer. In view of the important role of DNA repair in protection of the genomic stability, there is no doubt that these proteins will become powerful biomarkers not only for cancer, but also for other diseases.

\section{Conclusions}

Evidence accumulated over many years points to an important role of oxidatively induced DNA damage in the etiology of cancer. This type of damage occurs in living organisms endogenously due to oxygen metabolism and by a variety of exogenous sources. The existence of various repair mechanisms and repair proteins in vivo for the repair of oxidatively induced DNA lesions is a strong testament to the detrimental biological effects caused by these lesions in living organisms. Many of the lesions are strongly mutagenic leading to transition and transversion mutations that are commonly found in cancer. They also accumulate significantly in cancerous tissues when compared to normal tissues, possibly contributing to genomic instability and metastatic potential. Recent evidence suggests an increase of DNA repair in some types of tumors, which may cause resistance to therapy. There is evidence that defective DNA repair, and mutations and polymorphisms in DNA repair genes contribute to carcinogenesis. Oxidatively induced DNA lesions and DNA repair enzymes are potential cancer biomarkers.

DNA repair enzymes are emerging as important early detection, prognostic and therapeutic factors in cancer. DNA repair inhibitors are being developed to increase the efficacy of cancer therapy. More research in the field of oxidatively induced genomic DNA damage and its repair may lead to development of cancer biomarkers, DNA repair inhibitors and enhancement of our capabilities to understand and fight cancer.

\section{References}

1. Evans MD, Dizdaroglu M, Cooke MS (2004) Oxidative DNA damage and disease: induction, repair and significance. Mutat Res 567: 1-61.

2. Friedberg EC, Walker GC, Siede W, Wood RD, Schultz RA, et al. (2006) DNA Repair and Mutagenesis. ASM Press,Washington, DC

3. Halliwell B, Gutteridge JMC (2007) Free Radicals in Biology and Medicine Fourth Edition, Oxford University Press, Oxford.

4. von Sonntag C (2006) Free-Radical-Induced DNA Damage and Its Repair Springer, Hiedelberg

5. Wallace SS (2002) Biological consequences of free radical-damaged DNA bases. Free Radic Biol Med 33: 1-14.

6. Jackson AL, Loeb LA (2001) The contribution of endogenous sources of DNA damage to the multiple mutations in cancer. Mutat Res 477: 7-21.

7. Davidson JF, Guo HH, Loeb LA (2002) Endogenous mutagenesis and cancer Mutat Res 509: 17-21.

8. Loeb LA (2011) Human cancers express mutator phenotypes: origin consequences and targeting. Nature Rev Cancer 11: 450-457.

9. O'Neill P (1983) Pulse radiolytic study of the interaction of thiols and ascorbate with $\mathrm{OH}$ adducts of dGMP and dG: Implications for DNA repair processes. Radiat Res 96: 198-210.

10. Steenken S (1989) Purine bases, nucleosides, and nucleotides: Aqueous solution redox chemistry and transformation reactions of their radical cations and $\mathrm{e}-$ and $\mathrm{OH}$ adducts. Chem Rev 89: 503-520.

11. Vieira AJ, Steenken S (1990) Pattern of OH radical reaction with adenine and its nucleosides and nucleotides. Characterization of two types of isomeric $\mathrm{OH}$ adduct and their unimolecular transformation reactions. J Am Chem Soc 112 6986-6994.

12. Candeias LP Steenken S (2000) Reaction of $\mathrm{HO}^{*}$ with guanine derivatives in aqueous solution: Formation of two different redox-active $\mathrm{OH}$-adduct radicals and their unimolecular transformation reactions. Properties of $\mathrm{G}(-\mathrm{H})^{*}$. Chemistry European Journal 6: 475-484.

13. Dizdaroglu M, Holwitt E, Hagan MP, Blakely WF (1986) Formation of cytosine glycol and 5,6-dihydroxycytosine in deoxyribonucleic acid on treatment with osmium tetroxide. Biochem J 235: 531-536.

14. Dizdaroglu M, Jaruga P, Birincioglu M, Rodriguez H (2002) Free radicalinduced damage to DNA: mechanisms and measurement. Free Radic Biol Med 32: $1102-1115$

15. Sutherland BM, Bennett PV, Sidorkina O, Laval J (2000) Clustered DNA damages induced in isolated DNA and in human cells by low doses of ionizing radiation. Proc Natl Acad Sci U S A 97: 103-108.

16. David-Cordonnier MH, Laval J, O'Neill P (2000) Clustered DNA damage influence on damage excision by XRS5 nuclear extracts and Escherichia coli Nth and Fpg proteins. J Biol Chem 275: 11865-11873. 
17. Blaisdell JO, Harrison L, Wallace SS (2001) Base excision repair processing of radiation-induced clustered DNA lesions. Radiat Prot Dosimetry 97: 25-31.

18. Sutherland BM, Bennett PV, Sutherland JC, Laval J (2002) Clustered DNA damages induced by $x$ rays in human cells. Radiat Res 157: 611-616.

19. Keck K (1968) Formation of cyclonucleotides during irradiation of aqueous solutions of purine nucleotides. Z Naturforsch B 23: 1034-1043.

20. Chatgilialoglu C, Guerra M, Mulazzani QG (2003) Model studies of DNA C5 radicals. Selective generation and reactivity of 2'-deoxyadenosin-5'-yl radical. J Am Chem Soc 125: 3839-3848.

21. Manetto A, Georganakis D, Leondiadis L, Gimisis T, Mayer P, et al. (2007) Independent generation of C5'-nucleosidyl radicals in thymidine and 2'-deoxyguanosine. J Org Chem 72: 3659-3666.

22. Raleigh JA, Kremers W, Whitehouse R (1976) Radiation chemistry of nucleotides: 8,5'-cyclonucleotide formation and phosphate release initiated by hydroxyl radical attack on adenosine monophosphates. Radiat. Res 65: 414422.

23. Haromy TP, Raleigh J, Sundaralingam M (1980) Enzyme-bound conformations of nucleotide substrates. X-ray structure and absolute configuration of 8,5'-cycloadenosine monohydrate. Biochemistry 19: 1718-1722.

24. Miaskiewicz K, Miller JH, Fuciarelli AF (1995) Theoretical analysis of DNA intrastrand cross linking by formation of $8,5^{\prime}$-cyclodeoxyadenosine. Nucleic Acids Res 23: 515-521.

25. Jaruga P, Dizdaroglu M (2008) 8,5'-Cyclopurine-2'-deoxynucleosides in DNA: Mechanisms of formation, measurement, repair and biological effects. DNA Repair (Amst) 7: 1413-1425.

26. Dizdaroglu M, Gajewski E, Reddy P, Margolis SA (1989) Structure of a hydroxyl radical induced DNA-protein cross-link involving thymine and tyrosine in nucleohistone. Biochemistry 28: 3625-3628.

27. Nackerdien Z, Rao G, Cacciuttolo MA, Gajewski E, Dizdaroglu M (1991) Chemical nature of DNA-protein cross-links produced in mammalian chromatin by hydrogen peroxide in the presence of iron or copper ions. Biochemistry 30 : 4873-4879.

28. Olinski R, Nackerdien Z, Dizdaroglu M (1992) DNA-protein cross-linking between thymine and tyrosine in chromatin of gamma-irradiated or $\mathrm{H}_{2} \mathrm{O}_{2}$ treated cultured human cells. Archiv Biochem Biophys 297: 139-143.

29. Jaruga P, Kirkali G, Dizdaroglu M (2008) Measurement of formamidopyrimidines in DNA. Free Radic Biol Med 45: 1601-1609.

30. Malins DC, Ostrander GK, Haimanot R, Williams P (1990) A novel DNA lesion in neoplastic livers of feral fish: 2,6-diamino-4-hydroxy-5-formamidopyrimidine. Carcinogenesis 11: 1045-1047.

31. Malins DC, Haimanot R (1990) 4,6-Diamino-5-formamidopyrimidine, 8-hydroxyguanine and 8-hydroxyadenine in DNA from neoplastic liver of English sole exposed to carcinogens. Biochem Biophys Res Commun 173: 614-619.

32. Malins DC, Haimanot R (1991) Major alterations in the nucleotide structure of DNA in cancer of the female breast. Cancer Res 51: 5430-5432.

33. Olinski R, Zastawny T, Budzbon J, Skokowski J, Zegarski W, et al. (1992) DNA Base Modifications in Chromatin of Human Cancerous Tissues. FEBS Lett 309: 193-198.

34. Malins DC, Holmes EH, Polissar NL, Gunselman SJ (1993) The etiology of breast cancer: Characteristic alterations in hydroxyl radical-induced DNA base lesions during oncogenesis with potential for evaluating incidence risk. Cancer 71: $3036-3043$

35. Malins DC (1993) Identification of hydroxyl radical-induced lesions in DNA base structure: Biomarkers with a putative link to cancer development. J Toxicol Environ Health 40: 247-261.

36. Jaruga P, Zastawny TH, Skokowski J, Dizdaroglu M, Olinski R (1994) Oxidative DNA base damage and antioxidant enzyme activities in human lung cancer FEBS Lett 341: 59-64.

37. Malins DC, Johnson PM, Barker EA, Polissar NL, Wheeler TM, et al. (2003) Cancer-related changes in prostate DNA as men age and early identification of metastasis in primary prostate tumors. Proc Natl Acad Sci U S A 100: 5401 5406.
38. Anderson KM, Jaruga P, Ramsey CR, Gilman NK, Green VM, et al. (2006) Structural alterations in breast stromal and epithelial DNA: The influence of 8,5'-cyclo-2'-deoxyadenosine. Cell Cycle 5: 1240-1244.

39. Malins DC, Anderson KM, Stegeman JJ, Jaruga P, Green VM, e al. (2006) Biomarkers signal contaminant effects on the organs of English sole (Parophrys vetulus) from Puget Sound. Environ Health Perspect 114: 823-829.

40. Malins DC, Anderson KM, Jaruga P, Ramsey CR, Gilman NK, et al. (2006) Oxidative changes in the DNA of stroma and epithelium from the female breast: Potential implications for breast cancer. Cell Cycle 5: 1629-1632.

41. Nyaga SG, Lohani A, Jaruga P, Trzeciak AR, Dizdaroglu M, et al. (2006) Reduced repair of 8-hydroxyguanine in the human breast cancer cell line HCC1937. BMC Cancer 6: 297.

42. Doll R, Peto R (1981) The causes of cancer: quantitative estimates of avoidable risks of cancer in the United States today. J Natl Cancer Inst 66: 1191-1308.

43. Loeb LA (2010) Mutator phenotype in cancer: origin and consequences. Semin Cancer Biol 20: 279-280.

44. Hoeijmakers JH (2001) Genome maintenance mechanisms for preventing cancer. Nature 411: 366-374.

45. Fortini P, Parlanti E, Sidorkina OM, Laval J, Dogliotti E (1999) The type of DNA glycosylase determines the base excision repair pathway in mammalian cells J Biol Chem 274: 15230-15236.

46. Dizdaroglu M (2005) Base-excision repair of oxidative DNA damage by DNA glycosylases. Mutat Res 591: 45-59.

47. Aravind L, Walker DR, Koonin EV (1999) Conserved domains in DNA repai proteins and evolution of repair systems. Nucleic Acids Res 27: 1223-1242.

48. Eisen JA, Hanawalt PC (1999) A phylogenomic study of DNA repair genes, proteins, and processes. Mutat Res 435: 171-213.

49. Boiteux S, Gajewski E, Laval J, Dizdaroglu M (1992) Substrate specificity of the Escherichia coli Fpg protein (formamidopyrimidine-DNA glycosylase): excision of purine lesions in DNA produced by ionizing radiation or photosensitization. Biochemistry 31: 106-110.

50. Hazra TK, Izumi T, Boldogh I, Imhoff B, Kow YW, et al. (2002) Identification and characterization of a human DNA glycosylase for repair of modified bases in oxidatively damaged DNA. Proc Natl Acad Sci U S A 99: 3523-3528.

51. Bandaru V, Sunkara S, Wallace SS, Bond JP (2002) A novel human DNA glycosylase that removes oxidative DNA damage and is homologous to Escherichia coli endonuclease VIII. DNA Repair 1: 517-529.

52. Hazra TK, Kow YW, Hatahet Z, Imhoff B, Boldogh I, et al. (2002) Identification and characterization of a novel human DNA glycosylase for repair of cytosinederived lesions. J Biol Chem 277: 30417-30420.

53. Morland I, Rolseth V, Luna L, Rognes T, Bjørås M, et al. (2002) Human DNA glycosylases of the bacterial Fpg/MutM superfamily: an alternative pathway fo the repair of 8-oxoguanine and other oxidation products in DNA. Nucleic Acids Res 30: 4926-4936.

54. Jaruga P, Birincioglu M, Rosenquist TA, Dizdaroglu M (2004) Mouse NEIL1 protein is specific for excision of 2,6-diamino-4-hydroxy-5-formamidopyrimidine and 4,6-diamino-5-formamidopyrimidine from oxidatively damaged DNA Biochemistry 43: 15909-15914.

55. Roy LM, Jaruga P, Wood TG, McCullough AK, Dizdaroglu M, et al. (2007) Human polymorphic variants of the NEIL1 DNA glycosylase. J Biol Chem 282 15790- 15798.

56. Liu M, Bandaru V, Bond JP, Jaruga P, Zhao X, et al. (2010) The mouse ortholog of NEIL3 is a functional DNA glycosylase in vitro and in vivo. Proc Natl Acad Sci U S A 107: 4925-4930.

57. Dou H, Mitra S, Hazra TK (2003) Repair of oxidized bases in DNA bubble structures by human DNA glycosylases NEIL1 and NEIL2. J Biol Chem 278 : 49679-49684.

58. Dherin C, Radicella JP, Dizdaroglu M, Boiteux S (1999) Excision of oxidatively damaged DNA bases by the human alpha-hOgg1 protein and the polymorphic alphahOgg1 (Ser326Cys) protein which is frequently found in human populations. Nucleic Acids Res 27: 4001-4007.

59. Audebert M, Radicella JP, Dizdaroglu M (2000) Effect of single mutations in the OGG1 gene found in human tumors on the substrate specificity of the ogg protein. Nucleic Acids Res 28: 2672-2678. 
60. Sancar A (1994) Mechanisms of DNA excision repair. Science 266: 1954-1956.

61. Friedberg EC (2001) How nucleotide excision repair protects against cancer. Nat Rev Cancer 1: 22-33.

62. Bohr VA, Smith CA, Okumoto DS, Hanawalt PC (1985) DNA repair in an active gene: Removal of pyrimidine dimers from the DHFR gene of $\mathrm{CHO}$ cells is much more efficient than in the genome overall. Cell 40: 359-369.

63. Mellon I, Spivak G, HanawaltPC (1987) Selective removal of transcriptionblocking DNA damage from the transcribed strand of the mammalian DHFR gene. Cell 51: 241-249.

64. Mellon I, Hanawalt PC (1989) Induction of the Escherichia coli lactose operon selectively increases repair of its transcribed DNA strand. Nature 342: 95-98.

65. Sancar A, Lindsey-Boltz LA, Unsal-Kaçmaz K, Linn S (2004) Molecular mechanisms of mammalian DNA repair and the DNA damage checkpoints. Annu Rev Biochem 73: 39-85.

66. Huang JC, Hsu DS, Kazantsev A, Sancar A (1994) Substrate spectrum of human excinuclease: Repair of abasic sites, methylated bases, mismatches, and bulky adducts. Proc Natl Acad Sci USA 91: 12213-12217.

67. Lin JJ, Sancar A (1989) A new mechanism for repairing oxidative damage to DNA: (A)BC excinuclease removes AP sites and thymine glycols from DNA. Biochemistry 28: 7979-7984.

68. Reardon JT, Bessho T, Kung HC, Bolton PH, Sancar A (1997) In vitro repair of oxidative DNA damage by human nucleotide excision repair system: Possible explanation for neurodegeneration in Xeroderma pigmentosum patients. Proc Natl Acad Sci USA 94: 9463-9468.

69. Dizdaroglu M (1986) Free-radical-induced formation of an 8,5'-cyclo-2'deoxyguanosine moiety in deoxyribonucleic acid. Biochem J 238: 247-254.

70. Dizdaroglu M, Dirksen ML, Jiang HX, Robbins JH (1987) lonizing-radiationinduced damage in the DNA of cultured human cells. Identification of 8,5'-cyclo-2'- deoxyguanosine. Biochem J 241: 929-932.

71. Brooks PJ, Wise DS, Berry DA, Kosmoski JV, Smerdon MJ, et al. (2000) The oxidative DNA lesion 8,5'-(S)-cyclo-2'-deoxyadenosine is repaired by the nucleotide excision repair pathway and blocks gene expression in mammalian cells. J Biol Chem 275: 22355-22362.

72. Kuraoka I, Bender C, Romieu A, Cadet J, Wood RD, et al. (2000) Removal of oxygen free-radical-induced 5',8-purine cyclodeoxynucleosides from DNA by the nucleotide excision-repair pathway in human cells. Proc Natl Acad Sci U S A 97: 3832-3837.

73. Parker AR, Eshleman JR (2003) Human MutY: gene structure, protein functions and interactions, and role in carcinogenesis. Cell Mol Life Sci 60: 2064-2083.

74. Slupska MM, Baikalov C, Luther WM, Chiang JH, Wei YF, et al. (1996) Cloning and sequencing a human homolog $(h M Y H)$ of the Escherichia coli mutY gene whose function is required for the repair of oxidative DNA damage. J Bacteriol 178: 3885-3892.

75. Takao M, Zhang QM, Yonei S, Yasui A (1999) Differential subcellular localization of human MutY homolog $(h M Y H)$ and the functional activity of adenine:8-oxoguanine DNA glycosylase. Nucleic Acids Res 27: 3638-3644.

76. Tsai-Wu JJ, Su HT, Wu YL, Hsu SM, Wu CH (2000) Nuclear localization of the human mutY homologue hMYH. J Cell Biochem 77: 666-677.

77. Parker A, Gu Y, Lu AL (2000) Purification and characterization of a mammalian homolog of Escherichia coli MutY mismatch repair protein from calf liver mitochondria. Nucleic Acids Res 28: 3206-3215.

78. Ohtsubo T, Nishioka K, Imaiso Y, Iwai S, Shimokawa H, et al. (2000) Identification of human MutY homolog (hMYH) as a repair enzyme for 2-hydroxyadenine in DNA and detection of multiple forms of hMYH located in nuclei and mitochondria. Nucleic Acids Res 28: 1355-1364.

79. Al-Tassan N, Chmiel NH, Maynard J, Fleming N, Livingston AL, et al. (2002) Inherited variants of $\mathrm{MYH}$ associated with somatic G:C-->T:A mutations in colorectal tumors. Nat Genet 30: 227-232.

80. Jones S, Emmerson P, Maynard J, Best JM, Jordan S, et al. (2002) Biallelic germline mutations in MYH predispose to multiple colorectal adenoma and somatic G:C-->T:A mutations. Hum Mol Genet 11: 2961-2967.

81. Cheadle JP, Dolwani S, Sampson JR (2003) Inherited defects in the DNA glycosylase MYH cause multiple colorectal adenoma and carcinoma. Carcinogenesis 24: 1281-1282.
82. Cheadle,J.P and Sampson,J.R. (2007) MUTYH-associated polyposis--from defect in base excision repair to clinical genetic testing. DNA Repair (Amst) 6: 274-279.

83. Maki H, Sekiguchi M (1992) MutT protein specifically hydrolyses a potent mutagenic substrate for DNA synthesis. Nature 355: 273-275.

84. Mo JY, Maki H, Sekiguchi M (1992) Hydrolytic elimination of a mutagenic nucleotide, 8-oxodGTP, by human 18-kilodalton protein: sanitization of nucleotide pool. Proc Natl Acad Sci U S A 89: 11021-11025.

85. Tajiri T, Maki H, Sekiguchi M (1995) Functional cooperation of MutT, MutM and MutY proteins in preventing mutations caused by spontaneous oxidation of guanine nucleotide in Escherichia coli. Mutat Res 336: 257-267.

86. Sakumi K, Furuichi M, Tsuzuki T, Kakuma T, Kawabata S, et al. (1993) Cloning and expression of cDNA for a human enzyme that hydrolyzes 8-oxodGTP, a mutagenic substrate for DNA synthesis. J Biol Chem 268: 23524-23530.

87. Sekiguchi M, Tsuzuki T (2002) Oxidative nucleotide damage: consequences and prevention. Oncogene 21: 8895-8904

88. Tsuzuki T, Egashira A, Igarashi H, Iwakuma T, Nakatsuru Y, et al. (2001) Spontaneous tumorigenesis in mice defective in the MTH1 gene encoding 8-oxo-dGTPase. Proc Natl Acad Sci U SA 98: 11456-11461.

89. Sakai Y, Furuichi M, Takahashi M, Mishima M, Iwai S, et al. (2002) A molecula basis for the selective recognition of 2-hydroxy-dATP and 8-oxo-dGTP by human MTH1. J Biol Chem 277: 8579-8587.

90. Rouse J, Jackson SP (2002) Interfaces between the detection, signaling, and repair of DNA damage. Science 297: 547-551.

91. Jackson SP (2002) Sensing and repairing DNA double-strand breaks. Carcinogenesis 23: 687-696

92. Beckman RA, Loeb LA (2005) Genetic instability in cancer: theory and experiment. Semin Cancer Biol 15: 423-435.

93. Greenman C, Stephens P, Smith R, Dalgliesh GL, Hunter C, et al. (2007) Patterns of somatic mutation in human cancer genomes. Nature 446:153-158.

94. Goode EL, Ulrich CM, Potter JD (2002) Polymorphisms in DNA repair genes and associations with cancer risk. Cancer Epidemiol Biomarkers Prev 11 1513-1530.

95. Madhusudan S, Middleton MR (2005) The emerging role of DNA repair proteins as predictive, prognostic and therapeutic targets in cancer. Cancer Treat Rev 31: 603-617.

96. Helleday T, Petermann E, Lundin C, Hodgson B, Sharma RA (2008) DNA repair pathways as targets for cancer therapy. Nat Rev Cancer 8: 193-204.

97. Cheng L, Eicher SA, Guo Z, Hong WK, Spitz MR, et al. (1998) Reduced DNA repair capacity in head and neck cancer patients. Cancer Epidemiol Biomarkers Prev 7: 465-468.

98. Berwick M, Vineis P (2000) Markers of DNA repair and susceptibility to cance in humans: an epidemiologic review. J Natl Cancer Inst 92: 874-897.

99. Cheng L, Spitz MR, Hong WK, Wei Q (2000) Reduced expression levels of nucleotide excision repair genes in lung cancer: a case-control analysis. Carcinogenesis 21: 1527-1530.

100.Lippman SM, Spitz MR (2001) Lung cancer chemoprevention: an integrated approach. J Clin Oncol 19: 74S-82S.

101. Morimoto H, Tsukada J, Kominato Y, Tanaka Y (2005) Reduced expression of human mismatch repair genes in adult T-cell leukemia. Am J Hematol 78: 100-107.

102. Liu R, Yin LH, Pu YP (2007) Reduced expression of human DNA repair genes in esophageal squamous-cell carcinoma in china. J Toxicol Environ Health $A$ 70: 956-963.

103. Kohno T, Shinmura K, Tosaka M, Tani M, Kim SR, et al. (1998) Genetic polymorphisms and alternative splicing of the hOGG1 gene, that is involved in the repair of 8-hydroxyguanine in damaged DNA. Oncogene 16: 3219-3225.

104. Shinmura K, Kohno T, Kasai H, Koda K, Sugimura H, et al. (1998) Infrequent mutations of the hOGG1 gene, that is involved in the excision of 8-hydroxyguanine in damaged DNA, in human gastric cancer. Jpn J Cancer Res 89: 825-828.

105. Chevillard S, Radicella JP, Levalois C, Lebeau J, Poupon MF, et al. (1998) Mutations in OGG1, a gene involved in the repair of oxidative DNA damage, are found in human lung and kidney tumours. Oncogene 16: 3083-3086. 
106. Xing DY, Tan W, Song N, Lin DX (2001) Ser326Cys polymorphism in hOGG1 gene and risk of esophageal cancer in a Chinese population. Int J Cancer 95: 140-143.

107. Park YJ, Choi EY, Choi JY, Park JG, You HJ, et al. (2001) Genetic changes of hOGG1 and the activity of oh8Gua glycosylase in colon cancer. Eur J Cancer 37: $340-346$.

108. Elahi A, Zheng Z, Park J, Eyring K, McCaffrey T, et al. (2002) The human OGG1 DNA repair enzyme and its association with orolaryngeal cancer risk. Carcinogenesis 23: 1229-1234.

109. Ito H, Hamajima N, Takezaki T, Matsuo K, Tajima K, et al. (2002) A limited association of OGG1 Ser326Cys polymorphism for adenocarcinoma of the lung. J Epidemiol 12: 258-265.

110. Le Marchand L, Donlon T, Lum-Jones A, Seifried A, Wilkens LR (2002) Association of the hOGG1 Ser326Cys polymorphism with lung cancer risk. Cancer Epidemiol Biomarkers Prev 11: 409-412.

111. Tsukino H, Hanaoka T, Otani T, Iwasaki M, Kobayashi M, et al. (2004) hOGG1 Ser326Cys polymorphism, interaction with environmental exposures, and gastric cancer risk in Japanese populations. Cancer Sci 95: 977-983.

112. Hansen R, Saebø M, Skjelbred CF, Nexø BA, Hagen PC, et al. (2005) GPX Pro198Leu and OGG1 Ser326Cys polymorphisms and risk of development of colorectal adenomas and colorectal cancer. Cancer Lett 229: 85-91.

113. Niwa $Y$, Matsuo K, Ito H, Hirose K, Tajima K, et al. (2005) Association of XRCC1 Arg399GIn and OGG1 Ser326Cys polymorphisms with the risk of cervical cancer in Japanese subjects. Gynecol Oncol 99: 43-49.

114. Poplawski T, Arabski M, Kozirowska D, Blasinska-Morawiec M, Morawiec Z, et al. (2006) DNA damage and repair in gastric cancer--a correlation with the hOGG1 and RAD51 genes polymorphisms. Mutat Res 601: 83-91.

115. Kohno T, Kunitoh H, Toyama K, Yamamoto S, Kuchiba A, et al. (2006) Association of the OGG1-Ser326Cys polymorphism with lung adenocarcinoma risk. Cancer Sci 97: 724-728.

116. Jiao X, Huang J, Wu S, Lv M, Hu Y, et al. (2007) hOGG1 Ser326Cys polymorphism and susceptibility to gallbladder cancer in a Chinese population. Int J Cancer 121I: 501-505

117. Arizono K, Osada Y, Kuroda Y (2008) DNA repair gene hOGG1 codon 326 and $\mathrm{XRCC} 1$ codon 399 polymorphisms and bladder cancer risk in a Japanese population. Jpn J Clin Oncol 38: 186-191.

118. Hatt L, Loft S, Risom L, Møller P, Sørensen M, et al. (2008) OGG1 expression and OGG1 Ser326Cys polymorphism and risk of lung cancer in a prospective study. Mutat Res 639: 45-54.

119. Audebert M, Chevillard S, Levalois C, Gyapay G, Vieillefond A, et al. (2000) Alterations of the DNA repair gene OGG1 in human clear cell carcinomas of the kidney. Cancer Res 60: 4740-4744.

120. Gackowski D, Speina E, Zielinska M, Kowalewski J, Rozalski R, et al. (2003) Products of oxidative DNA damage and repair as possible biomarkers of susceptibility to lung cancer. Cancer Res 63: 4899-4902.

121.Paz-Elizur T, Krupsky M, Blumenstein S, Elinger D, Schechtman E, et al (2003) DNA repair activity for oxidative damage and risk of lung cancer. J Nat Cancer Inst 95: 1312-1319.

122. Paz-Elizur T, Elinger D, Leitner-Dagan $Y$, Blumenstein S, Krupsky M, et al. (2007) Development of an enzymatic DNA repair assay for molecula epidemiology studies: distribution of OGG activity in healthy individuals. DNA Repair (Amst) 6: 45-60.

123. Tudek B (2007) Base excision repair modulation as a risk factor for human cancers. Mol Aspects Med 28: 258-275.

124. El-Zein RA, Monroy CM, Cortes A, Spitz MR, Greisinger A, et al. (2010) Rapid method for determination of DNA repair capacity in human peripheral blood lymphocytes amongst smokers. BMC Cancer 10: 439

125. Takao M, Kanno S, Kobayashi K, Zhang QM, Yonei S, et al. (2002) A back-up glycosylase in Nth1 knock-out mice is a functional Nei (endonuclease VIII) homologue. J Biol Chem 277: 42205-42213.

126. Rosenquist TA, Zaika E, Fernandes AS, Zharkov DO, Miller $\mathrm{H}$, et al (2003) The novel DNA glycosylase, NEIL1, protects mammalian cells from radiationmediated cell death. DNA Repair (Amst) 2: 581-591.

127.Doublié S, Bandaru V, Bond JP, Wallace SS (2004) The crystal structure of human endonuclease VIII-like 1 (NEIL1) reveals a zincless finger motif required for glycosylase activity. Proc Natl Acad Sci U S A 101: 10284-10289.

128. Hailer MK, Slade PG, Martin BD, Rosenquist TA, Sugden KD, et al (2005) Recognition of the oxidized lesions spiroiminodihydantoin and guanidinohydantoin in DNA by the mammalian base excision repair glycosylases NEIL1 and NEIL2. DNA Repair (Amst) 4: 41-50.

129. Hu J, de Souza-Pinto NC, Haraguchi K, Hogue BA, Jaruga P, et al. (2005) Repair of formamidopyrimidines in DNA involves different glycosylases: role of the OGG1, NTH1, and NEIL1 enzymes. J Biol Chem 280: 40544-40551.

130. Krishnamurthy N, Zhao X, Burrows CJ, David SS (2008) Superior Removal of Hydantoin Lesions Relative to Other Oxidized Bases by the Human DNA Glycosylase hNEIL1. Biochemistry 47: 7137-7146.

131. Muftuoglu M, de Souza-Pinto NC, Dogan A, Aamann M, Stevnsner T, et al. (2009) Cockayne syndrome group B protein stimulates repair of formamidopyrimidines by NEIL1 DNA glycosylase. J Biol Chem 284: $9270-$ 9279

132. Izumi T, Wiederhold LR, Roy G, Roy R, Jaiswal A, et al. (2003) Mammalian DNA base excision repair proteins: their interactions and role in repair of oxidative DNA damage. Toxicology 193: 43-65

133. Maiti AK, Boldogh I, Spratt H, Mitra S, Hazra TK (2008) Mutator phenotype of mammalian cells due to deficiency of NEIL1 DNA glycosylase, an oxidized base-specific repair enzyme. DNA Repair (Amst) 7: 1213-1220.

134. Das A, Hazra TK, Boldogh I, Mitra S, Bhakat KK (2005) Induction of the human oxidized base-specific DNA glycosylase NEIL1 by reactive oxygen species. $J$ Biol Chem 280: 35272-35280.

135. Shinmura K, Tao H, Goto M, Igarashi H, Taniguchi T, et al. (2004) Inactivating mutations of the human base excision repair gene NEIL1 in gastric cancer. Carcinogenesis 25: 2311-2317.

136. Vartanian V, Lowell B, Minko IG, Wood TG, Ceci JD, et al. (2006) The metabolic syndrome resulting from a knockout of the NEIL1 DNA glycosylase. Proc Natl Acad Sci U S A 103: 1864-1869.

137. Chan MK, Ocampo-Hafalla MT, Vartanian V, Jaruga P, Kirkali G, et al (2009) Targeted deletion of the genes encoding NTH1 and NEIL1 DNA $\mathrm{N}$-glycosylases reveals the existence of novel carcinogenic oxidative damage to DNA. DNA Repair (Amst) 8: 786-794.

138. Xie Y, Yang H, Cunanan C, Okamoto K, Shibata D, et al. (2004) Deficiencies in mouse Myh and Ogg1 result in tumor predisposition and $\mathrm{G}$ to T mutations in codon 12 of the K-ras oncogene in lung tumors. Cancer Res 64: 3096-3102.

139. Jaruga $P$, Xiao Y, Vartanian V, Lloyd RS, Dizdaroglu M (2010) Evidence for the involvement of DNA repair enzyme NEIL1 in nucleotide excision repair of $\left(5^{\prime} R\right)$ - and (5'S)-8,5'-cyclo-2'-deoxyadenosines. Biochemistry 49: 1053-1055.

140. Kirkali G, de Souza-Pinto NC, Jaruga P, Bohr VA, Dizdaroglu M (2009) Accumulation of (5'S)-8,5'-cyclo-2'-deoxyadenosine in organs of Cockayne syndrome complementation group B gene knockout mice. DNA Repair (Amst) 8: $274-278$

141.Bosken $\mathrm{CH}$, Wei Q, Amos Cl, Spitz MR (2002) An analysis of DNA repair as a determinant of survival in patients with non-small-cell lung cancer. J Nat Cancer Inst 94: 1091-1099.

142. Lord RV, Brabender J, Gandara D, Alberola V, Camps C, et al. (2002) Low ERCC1 expression correlates with prolonged survival after cisplatin plus gemcitabine chemotherapy in nonsmall cell lung cancer. Clin. Cancer Res 8 2286-2291.

43. Rosell R, Taron M, Barnadas A, Scagliotti G, Sarries C, et al. (2003) Nucleotide excision repair pathways involved in Cisplatin resistance in non-small-cell lung cancer. Cancer Control 10: 297-305

144. Mambo E, Chatterjee A, de Souza-Pinto NC, Mayard S, Hogue BA, et al. (2005) Oxidized guanine lesions and hOgg1 activity in lung cancer. Oncogene 24: $4496-4508$

145. Schmid K, Nair J, Winde G, Velic I, Bartsch H (2000) Increased levels of promutagenic etheno-DNA adducts in colonic polyps of FAP patients. Int $J$ Cancer 87: 1-4.

146. Obtulowicz T, Swoboda M, Speina E, Gackowski D, Rozalski R, et al. (2010) Oxidative stress and 8-oxoguanine repair are enhanced in colon adenoma and carcinoma patients. Mutagenesis 25: 463-471. 
147. Wood ML, Dizdaroglu M, Gajewski E, Essigmann JM (1990) Mechanistic studies of ionizing radiation and oxidative mutagenesis: genetic effects of a single 8-hydroxyguanine (7-hydro-8-oxoguanine) residue inserted at a unique site in a viral genome. Biochemistry 29: 7024-7032.

148. Shibutani S, Takeshita M, Grollman AP (1991) Insertion of specific bases during DNA synthesis past the oxidation-damaged base 8-oxodG. Nature 349: 431-434.

149. Cheng KC, Cahill DS, Kasai H, Nishimura S, Loeb LA (1992) 8-Hydroxyguanine, an abundant form of oxidative DNA damage, causes G-T and A-C substitutions J Biol Chem 267: 166-172.

150. Grollman AP, Moriya M (1993) Mutagenesis by 8-oxoguanine: An enemy within. Trends Genet 9: 246-249.

151. Olivier M, Hollstein M, Hainaut P (2010) TP53 mutations in human cancers: origins, consequences, and clinical use. Cold Spring Harb Perspect Biol 2 : a001008.

152. Guschlbauer W, Duplaa AM, Guy A, Téoule R, Fazakerley GV (1991) Structure and in vitro replication of DNA templates containing 7,8-dihydro-8-oxoadenine. Nucleic Acids Res 19: 1753-1758.

153. Kamiya H, Miura H, Murata-Kamiya N, Ishikawa H, Sakaguchi T, et al. (1995) 8-hydroxyadenine (7,8-dihydro-8-oxoadenine) induces misincorporation in in vitro DNA synthesis and mutations in NIH 3 T3 cells. Nucleic Acids Res 23 2893-2899.

154.Tan X, Grollman AP, Shibutani S (1999) Comparison of the mutagenic properties of 8-oxo-7,8-dihydro-2'- deoxyadenosine and 8-oxo-7,8-dihydro-2'deoxyguanosine DNA lesions in mammalian cells. Carcinogenesis 20: $2287-$ 2292.

155. Chetsanga CJ, Lindahl T (1979) Release of 7-methylguanine residues whose imidazole rings have been opened from damaged DNA by a DNA glycosylase from Escherichia coli. Nucleic Acids Res 6: 3673-3684.

156. Chetsanga CJ, Bearie B, Makaroff C (1982) Alkaline opening of imidazole ring of 7 -methylguanosine. 1. Analysis of the resulting pyrimidine derivatives. Chem Biol Interact 41: 217-233.

157. Boiteux S, Laval J (1983) Imidazole open ring 7-methylguanine: an inhibitor of DNA synthesis. Biochem Biophys Res Commun 110: 552-558.

158. Boiteux S, Belleney J, Roques BP, Laval J (1984) Two rotameric forms of open ring 7-methylguanine are present in alkylated polynucleotides. Nucleic Acids Res 12: 5429-5439.

159. Tudek B, Graziewicz M, Kazanova O, Zastawny TH, Obtułowicz T, et al. (1999) Mutagenic specificity of imidazole ring-opened N7-methylguanine in M13mp18 phage DNA. Acta Biochim. Pol 46: 785-799.

160.Delaney MO, Wiederholt CJ, Greenberg MM (2002) Fapy-dA induces nucleotide misincorporation tranlesionally by a DNA polymerase. Angew Chem Int Ed Engl 41: 771-775.

161. Kalam MA, Haraguchi K, Chandani S, Loechler EL, Moriya M, et al. (2006) Genetic effects of oxidative DNA damages: comparative mutagenesis of the imidazole ring-opened formamidopyrimidines (Fapy lesions) and 8-oxopurines in simian kidney cells. Nucleic Acids Res 34: 2305-2315.

162. Wiederholt CJ, Greenberg MM (2002) Fapy.dG instructs Klenow exo(-) to misincorporate deoxyadenosine. J Am Chem Soc 124: 7278-7679.

163. Patro JN, Wiederholt CJ, Jiang YL, Delaney JC, Essigmann JM, et al. (2007) Studies on the replication of the ring opened formamidopyrimidine, Fapy.dG in Escherichia coli. Biochemistry 46:10202-10212.

164. Nackerdien Z, Kasprzak KS, Rao G, Halliwell B, Dizdaroglu M (1991) Nickel(II)and cobalt(II)-dependent damage by hydrogen peroxide to the DNA bases in isolated human chromatin. Cancer Res 51: 5837-5842.

165. Kamiya H, Kasai H (1997) Mutations induced by 2-hydroxyadenine on a shuttle vector during leading and lagging strand syntheses in mammalian cells. Biochemistry 36: 11125-11130.

166. Robinson H, Gao YG, Bauer C, Roberts C, Switzer C, et al. (1998) 2'Deoxyisoguanosine adopts more than one tautomer to form base pairs with thymidine observed by high-resolution crystal structure analysis. Biochemistry 37: 10897-10905.

167. Dizdaroglu M, Laval J, Boiteux S (1993) Substrate specificity of the Escherischia coli endonuclease III: excision of thymine- and cytosine-derived lesions in DNA produced by ionizing radiation-generated free radicals. Biochemistry $32: 12105-12111$
168. Purmal AA., Kow YW, Wallace SS (1994) Major oxidative products of cytosine 5- hydroxycytosine and 5-hydroxyuracil, exhibit sequence context-dependent mispairing in vitro. Nucleic Acids Res 22: 72-78.

169. Kreutzer DA, Essigmann JM, (1998) Oxidized, deaminated cytosines are a source of C --> T transitions in vivo. Proc Natl Acad Sci USA 95: 3578-3582.

170. Purmal AA., Lampman GW, Bond JP, Hatahet Z, Wallace SS (1998) Enzymatic processing of uracil glycol, a major oxidative product of DNA cytosine. J Bio Chem 273: 10026-10035.

171. Tkeshelasnvili LK, McBride T, Spence K, Loeb LA (1991) Mutation spectrum of copper-induced DNA damage. J Biol Chem 266: 6401-6406.

172. Feig DI, Sowers LC, Loeb LA (1994) Reverse chemical mutagenesis: identification of the mutagenic lesions resulting from reactive oxygen speciesmediated damage to DNA. Proc Natl Acad Sci USA 91: 6609-6613.

173.Wang D, Kreutzer DA, Essigmann JM (1998) Mutagenicity and repair of oxidative DNA damage: insights from studies using defined lesions. Mutat Res. 400: 99-115.

174. Reid TM, Loeb LA (1993) Tandem double CC-->TT mutations are produced by reactive oxygen species. Proc Natl Acad Sci USA 90: 3904-3907.

175. Hayes RC, Petrullo LA., Huang H, Wallace SS, LeClerc JE (1988) Oxidative damage in DNA. Lack of mutagenicity by thymine glycol lesions. J Mol Biol 201: 239-246.

176. Aller P, Rould MA, Hogg M, Wallace SS, Doublie S(2007) A structural rationale for stalling of a replicative DNA polymerase at the most common oxidative thymine lesion, thymine glycol. Proc Natl Acad Sci USA 104: 814-818.

177. Basu AK, Loechler EL, Leadon SA, Essigmann JM(1989) Genetic effects of thymine glycol: site-specific mutagenesis and molecular modeling studies. Proc Natl Acad Sci USA 86: 7677-7681.

178. Clark JM, Beardsley GP(1986) Thymine glycol lesions terminate chain elongation by DNA polymerase I in vitro. Nucleic Acids Res 14: 737-749.

179. Hayes RC, LeClerc JE (1986) Sequence dependence for bypass of thymine glycols in DNA by DNA polymerase I. Nucleic Acids Res 14: 1045-1061.

180. McNulty JM, Jerkovic B, Bolton PH, Basu AK (1998) Replication inhibition and miscoding properties of DNA templates containing a site-specific cis-thymine glycol or urea residue. Chem Res Toxicol.11: 666-673.

181. Kuraoka I, Robins P, Masutani C, Hanaoka F, Gasparutto D, et al. (2001) Oxygen free radical damage to DNA. Translesion synthesis by human DNA polymerase eta and resistance to exonuclease action at cyclopurine deoxynucleoside residues. J Biol Chem 276: 49283-49288.

182. Marietta C, Gulam H, Brooks PJ (2002) A single 8,5'-cyclo-2'-deoxyadenosine lesion in a TATA box prevents binding of the TATA binding protein and strongly reduces transcription in vivo. DNA Repair (Amst) 1: 967-975.

183. Marietta C, Brooks PJ (2007) Transcriptional bypass of bulky DNA lesions causes new mutant RNA transcripts in human cells. EMBO Rep 8: 388-393.

184. Doetsch PW (2002) Translesion synthesis by RNA polymerases: occurrence and biological implications for transcriptional mutagenesis. Mutat Res 510: $131-140$.

185. Brooks PJ (2002) DNA repair in neural cells: basic science and clinical implications. Mutat Res 509: 93-108.

186. Jasti VP, Das RS, Hilton BA, Weerasooriya S, Zou Y, Basu AK (2011) (5'S) 8,5'-Cyclo-2'-deoxyguanosine Is a strong block to replication, a potent po V-dependent mutagenic lesion, and is inefficiently repaired in Escherichia coli. Biochemistry 50: 3862-3865.

187. Egler RA, Fernandes E, Rothermund K, Sereika S, de Souza-Pinto N, et al. (2005) Regulation of reactive oxygen species, DNA damage, and c-Myc function by peroxiredoxin 1 . Oncogene $24: 8038-8050$.

188. Kirkali G, Tunca M, Genc S, Jaruga P, Dizdaroglu M (2008) Oxidative DNA damage in polymorphonuclear leukocytes of patients with familial Mediterranean fever. Free Radic Biol Med 44: 386-393.

189. Nyaga SG, Jaruga P, Lohani A., Dizdaroglu M, Evans MK (2007) Accumulation of oxidatively induced DNA damage in human breast cancer cell lines following treatment with hydrogen peroxide. Cell Cycle 6: 1472-1478.

190. Rodriguez H, Jaruga P, Leber D, Nyaga SG, Evans MK, Dizdaroglu M (2007) Lymphoblasts of women with BRCA1 mutations are deficient in cellular repair of 8,5'- Cyclopurine-2'-deoxynucleosides and 8-hydroxy-2'-deoxyguanosine. Biochemistry 46: 2488-2496. 
191. Cathcart R, Schwiers E, Saul R L, Ames BN (1984) Thymine glycol and thymidine glycol in human and rat urine: a possible assay for oxidative DNA damage. Proc Natl Acad Sci USA 81: 5633-5637.

192. Shigenaga MK, Gimeno CJ, Ames BN (1989) Urinary 8-hydroxy-2'deoxyguanosine as a biological marker of in vivo oxidative DNA damage. Proc Natl Acad Sci USA 86: 9697-9701.

193. Evans MD, Olinski R, Loft S, Cooke MS (2010) Toward consensus in the analysis of urinary 8-oxo-7,8-dihydro-2'-deoxyguanosine as a noninvasive biomarker of oxidative stress. FASEB J 24: 1249-1260.

194. Cooke MS, Olinski R, Loft S (2008) Measurement and meaning of oxidatively modified DNA lesions in urine. Cancer Epidemiol. Biomarkers Prev. 17: 3-14.

195. Gackowski D, Rozalski R, Roszkowski K, Jawien A, Foksinski M, et al. (2001) 8-Oxo-7,8-dihydroguanine and 8-oxo-7,8-dihydro-2'-deoxyguanosine levels in human urine do not depend on diet. Free Radic Res 35: 825-832.

196. Weimann A., Riis B, Poulsen HE (2004) Oligonucleotides in human urine do not contain 8-oxo-7,8-dihydrodeoxyguanosine. Free Radic Biol Med 36: 13781382

197. Siomek A, Tujakowski J, Gackowski D, Rozalski R, Foksinski M, et al. (2006) Severe oxidatively damaged DNA after cisplatin treatment of cancer patients. Int J Cancer 119: 2228-2230.

198. Rozalski R, Siomek A, Gackowski D, Foksinski M, Gran C, et al. (2005) Substantial decrease of urinary 8-oxo-7,8-dihydroguanine, a product of the base excision repair pathway, in DNA glycosylase defective mice. Int $J$ Biochem Cell Biol 37: 1331-1336.
199. Hayakawa H, Taketomi A., Sakumi K, Kuwano M, Sekiguchi M (1995) Generation and elimination of 8-oxo-7,8-dihydro-2'-deoxyguanosine 5'-triphosphate, a mutagenic substrate for DNA synthesis, in human cells. Biochemistry 34: 89-95.

200. Haghdoost S, Sjolander L, Czene S, Harms-Ringdahl M (2006) The nucleotide pool is a significant target for oxidative stress. Free Radic Biol Med 41: 620626.

201. Ravanat JL, Guicherd P, Tuce Z, Cadet J (1999) Simultaneous determination of five oxidative DNA lesions in human urine Chem Res Toxicol 12: 802-808.

202. Malayappan B, Garrett TJ, Segal M, Leeuwenburgh C (2007) Urinary analysis of 8-oxoguanine, 8-oxoguanosine, fapy-guanine and 8-oxo-2'-deoxyguanosine by highperformance liquid chromatography-electrospray tandem mass spectrometry as a measure of oxidative stress. J Chromatogr A 1167: 54-62.

203. Jaruga $P$, Dizdaroglu $M(2010)$ Identification and quantification of $\left(5^{\prime} R\right)$ - and (5'S)-8,5'-cyclo-2'-deoxyadenosines in human urine as putative biomarkers of oxidatively induced damage to DNA. Biochem Biophys Res Commun 397: 48-52.

204. Reddy PT, Jaruga P, Nelson BC, Lowenthal M, Dizdaroglu M (2011) Stable isotope-labeling of DNA repair proteins, and their purification and characterization. Protein Expr Purif 78: 94-101.

205. Dizdaroglu M, Reddy PT, Jaruga P (2011) Identification and quantification of DNA repair proteins by liquid chromatography/isotope-dilution tandem mass spectrometry using their fully ${ }^{15} \mathrm{~N}$-labeled analogues as internal standards. $J$ Proteome Res 10: 3802-3813. 